\title{
A Global Review of Insurance Industry Responses to Climate Change
}

\author{
Evan Mills \\ EETD, Lawrence Berkeley National Laboratory, 1 Cyclotron Road, MS 90-4000, Berkeley, California \\ 94720, USA. \\ E-mail: emills@1bl.gov
}

A vanguard of insurers is adapting its business model to the realities of climate change. In many ways, insurers are still catching up both to mainstream science and to their customers, which, in response to climate change and energy volatility, are increasingly changing the way they construct buildings, transport people and goods, design products and produce energy. Customers, as well as regulators and shareholders, are eager to see insurers provide more products and services that respond to the "greening" of the global economy, expand their efforts to improve disaster resilience and otherwise be proactive about the climate change threat. Insurers are increasingly recognising the issue as one of "enterprise risk management" (ERM), one cutting across the domains of underwriting, asset management and corporate governance. Their responses are becoming correspondingly sophisticated. Based on a review of more than 300 source documents, plus a direct survey of insurance companies, we have identified 643 specific activities from 244 insurance entities from 29 countries, representing a 50 per cent year-over-year increase in activity. These entities collectively represent $\$ 1.2$ trillion in annual premiums and $\$ 13$ trillion in assets, while employing 2.2 million people. In addition to activities on the part of 189 insurers, eight reinsurers, 20 intermediaries and 27 insurance organisations, we identified 34 non-insurance entities that have collaborated in these efforts. Challenges and opportunities include bringing promising products and services to scale, continuing to identify and fill market and coverage gaps and identifying and confirming the veracity of green improvements. There is also need for convergence between sustainability and disaster resilience, greater engagement by insurers in adaptation to unavoidable climate changes and to clarify the role that regulators will play in moving the market. It has not yet been demonstrated how some insurance lines might respond to climate change and a number of market segments have not yet been served with a single green insurance product or service. As insurer activities obtain more prominence, they also will be subject to more scrutiny and expectations that they are not simply greenwashing. The Geneva Papers (2009) 34, 323-359. doi:10.1057/gpp.2009.14

Keywords: climate change; insurance; energy systems; innovation

\section{Introduction}

A healthy and sustainable environment is a precursor to the long-term well-being of society, the strength of the economy and the continuing success of our business. We recognise that climate change is one of the most significant risks facing the world today ...

Marsh \& McLennan ${ }^{1}$

\footnotetext{
${ }^{1}$ Marsh (2007).
} 
Climate change is a fact. Countering it is a must. We are convinced that climate protection makes economic sense, as it would be more expensive in the long term to pay for the damage it causes. It offers companies and national economies that react quickly great opportunities ...

Peter Hoeppe, Munich $\mathrm{Re}^{2}$

\section{Taking the temperature of the insurance industry}

The insurance sector finds itself on the front lines of climate change and its response to the challenge has varied enormously. Insurers are, by definition, selective and cannot be expected to insure all risks. At a minimum, insurers can be messengers of climate risks through their pricing, terms and conditions and help society diversify the costs of losses. Insurers are intrinsically vulnerable and, in some cases, hampered by insufficient data. They are also increasingly challenged to make a greater effort to safeguard customers from natural hazards, before limiting coverage or exiting markets.

Mainstream insurers have increasingly come to see climate change as a material risk to their business. The worldwide economic losses from weather-related natural disasters were about $\$ 130$ billion in 2008 ( $\$ 44$ billion insured), ${ }^{3}$ and the losses have been rising more quickly than population or inflation. ${ }^{4}$

A 2007 PricewaterhouseCoopers survey of 100 insurance industry representatives from 21 countries indicates climate change is the number-four issue (out of 33); natural disasters ranks number two. ${ }^{5}$ The majority of the other issues are arguably compounded by climate change. The following year, Ernst \& Young surveyed more than 70 insurance industry analysts around the world to determine the top-10 risks facing the industry. ${ }^{6}$ Climate change was rated number one and most of the remaining 10 topics (e.g. catastrophe events and regulatory intervention) are also compounded by climate change. The investigators note that "it was surprising that this risk, which is typically viewed as a long-term issue, would be identified as the greatest strategic threat for the insurance industry".

Progress in scientific understanding is no doubt driving the growing engagement of insurers. The scientific debate is over, with the Intergovernmental Panel on Climate Change (IPCC) - representing the definitive scientific consensus and receiving the Nobel Peace Prize in 2007 for its work - now using the considered term "unequivocal" in describing its certainty that climate change is here. IPCC has also pinpointed human activity as the main driver of observed and projected warming. It has been steadily eliminating sources of uncertainty and reinforcing the conclusion that further delaying action would be highly ill-advised. Indeed, many indicators of climate change are evolving more quickly than projected by IPCC.

\footnotetext{
2 MEAG (2008).

${ }^{3}$ Swiss Re (2009).

${ }^{4}$ Mills (2005).

${ }^{5}$ PricewaterhouseCoopers (2007).

${ }^{6}$ Ernst and Young (2008)
} 
The economic analysis has shifted as well, as reports (such as the U.K. government's "Stern Review") ${ }^{7}$ turn on its head the conventional wisdom that taking action on climate change will harm the economy. Companies and investors now increasingly realise that, in fact, it is the lack of action to combat climate change that is the true threat to the economy, while engaging with the problem and mounting solutions represents not only a duty to shareholders but also a boon for economic growth.

Many in the insurance world share the concern. In the words of an associate editor at National Underwriter: "Given the stakes for insurers covering catastrophic losses, waiting for proof instead of taking action now would amount to just plain foolish behaviour". 8

The insurance community has become increasingly accepting of the science and macroeconomic modelling. Some still prefer to dismiss the science or take remaining uncertainties as a reason to wait on the sidelines, while others take it as precisely the reason for insurers not to be complacent. Most agree that reducing vulnerability to weather extremes should be a higher priority, but some dispute the need for insurers to engage in addressing the core drivers of climate change or the need to discern the relative roles of human influence and natural factors. ${ }^{9}$

Insurers' own analyses have provided a sobering outlook for insured economic risks and one that is increasingly consistent with what scientists predict for the physical world. Modelling studies conducted by the Association of British Insurers ${ }^{10}$ find that losses in typical and extreme future years will exceed today's by a factor of two or three.

Even those insurers who did not partake in earlier waves of insurer engagement on climate change are now publicly recognising its potential threats. State Farm $^{11}$ is "concerned about the prospect of global climate change, its possible impact on severe weather patterns and the challenges this presents to the business of insurance".

Allstate - insurer of one in nine vehicles and one in eight homes in the United States - recognises the onset of climate change and the presence of human fingerprints:

Allstate recognises the emerging scientific consensus that the world is getting warmer and that this trend is influenced to some extent by emissions of greenhouse gases. Climate change, to the extent it produces rising temperatures and changes in weather patterns, could impact the frequency or severity of extreme weather events and wildfires. Such changes could also impact the affordability and availability of homeowners insurance.

(Response to 2008 Carbon Disclosure Project Survey)

\footnotetext{
${ }^{7}$ The Stern Review on the Economics of Climate Change (2006).

${ }^{8}$ Ruquet (2007).

${ }^{9}$ Friedman (2007).

${ }^{10}$ ABI (2007).

${ }^{11}$ State Farm (2007).
} 
The chairman of Lloyd's of London has said that climate change is the number-one issue for the massive insurance market. Europe's largest insurer, Allianz, stated that climate change stands to increase insured losses from extreme events in an average year by 37 per cent within just a decade, while losses in a bad year could top $\$ 400$ billion. ${ }^{12}$ UNEP has put the value at $\$ 1$ trillion by the year $2040 .{ }^{13}$

The initial reaction of many insurers - particularly in the United States - has been to focus on financial means for limiting their exposure to losses, e.g. by limiting availability, tightening terms and raising prices. ${ }^{14,15}$ The availability-affordability issue places a bright light on the respective roles of the public sector and insurers, ${ }^{16}$ and the likelihood that government will have to assume more climate risks if the private sector recedes. This comes as the existing subsidy-based model for public flood insurance in the United States - the FEMA-managed National Flood Insurance Program ${ }^{17}$ - was rendered insolvent in 2005 by Hurricane Katrina and again in 2008 by Hurricane Ike, with a combined deficit approaching $\$ 30$ billion.

\section{Climate change as the ultimate ERM challenge}

Climate change - and how to respond to it - is not "yet another" issue for insurers. It is, rather, bound up in the very fabric of the industry and its business environment, namely:

- customer loyalty and retention;

- corporate governance, investor relations and disclosure;

- balance sheet strength, risk-based capital and solvency;

- competitiveness;

- emerging markets;

- reputation and trust;

- loss-model accuracy;

- regulation

Moreover, in addition to existing risks, the very technological and behavioural responses to climate change will usher in new risks. Examples include safety issues associated with a resurgence of nuclear power, or geo-engineering to cool the climate by heroic measures such as injecting man-made materials into the atmosphere, or the

\footnotetext{
${ }^{12}$ MacDonald-Smith (2007).

${ }^{13}$ Dlugolecki (2006).

${ }^{14}$ Mills et al. (2006).

${ }^{15}$ The Independent Insurance Agents \& Brokers of America found that nearly 3.0 million U.S. households have lost their homeowners coverage between 2003 and mid-2007; of that number, only half stated that they were able to find new coverage (IIABA, 2007). Those retaining their insurance have had to face price increases of 75 per cent in many states and up to 500 per cent in particularly risky areas (Environmental Defense, 2007). For more on this subject, see http://insurance.lbl.gov/ availability-affordability.

16 GAO (2007).

${ }^{17}$ Postal (2008).
} 


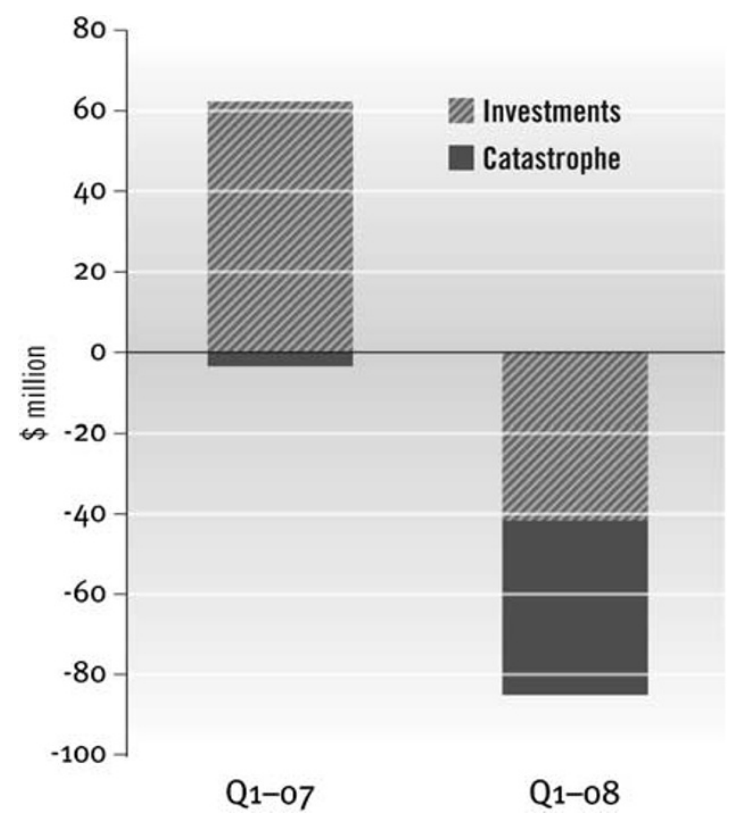

Figure 1. The "Perfect Storm" - Cincinatti Financial Results: Q1 2007 and Q1 2008 (Source: Greenwald, 2008).

introduction of carbon capture and storage (CCS) technology. Even some "green" strategies will bring with them new risks, while mitigating old ones.

As such, climate change is a textbook example of ERM, a framework that has resonated very strongly with the insurance community in recent years by integrating an otherwise fragmented risk-management process. ERM recognises the combined influence of internal and external pressures and how they interact across a broad portfolio of activities, including underwriting and asset management operations. The Casualty Actuarial Society notes that ERM "expresses risk not just as a threat, but as an opportunity". ${ }^{18}$

The past year's results for many companies put in sharp relief the potential for simultaneous spikes in uncorrelated natural catastrophe losses and adverse market conditions (Figure 1). The global industry saw huge insured catastrophe losses, superimposed on a financial meltdown and softening of insurance prices.

The recent volatility and spike in energy prices provides an excellent illustration of seemingly uncorrelated influences. For example, observers have suggested that opposition to credit scoring for personal auto underwriting could be amplified as the rising costs of gasoline create a cost crunch for consumers. ${ }^{19}$ Meanwhile, both consumer organisations and the governor of New York have argued that the

\footnotetext{
${ }^{18}$ CAS (2003).

${ }^{19}$ Bennett (2007).
} 
price-elasticity effect of rising gasoline prices has reduced the amount of driving and thus should translate into reduced premiums. ${ }^{20}$ This argument has been used in support of the California insurance regulator's recent effort to encourage pay-as-you-drive insurance. ${ }^{21}$ Some argue that the increased price of energy has driven up the cost of repair parts, offsetting gains resulting from reduced driving. ${ }^{22}$ Meanwhile, shifts in vehicle transportation choices can accentuate other risks, for example, those associated with van pools or telecommuting. ${ }^{23}$ Observers have noted adverse implications for risk management in the airline industry, spanning financial and safety considerations. ${ }^{24}$ Taking all of these factors into account, at least one major carrier (GEICO) withdrew a pre-existing rate increase request. ${ }^{25}$

\section{Global (business) climate change}

Irrespective of how a given insurer interprets the science of climate change, insurers are increasingly aware that the business environment is changing around them. In terms of risk perception, investors, rating companies, banks, customers, risk managers and regulators are each in their own way perceiving climate change as a threat and looking to those they interact with - including insurers - to support their response. For example, in 2008 major investment banks issued statements of concern about financing coal-fired power plants. ${ }^{26}$ Meanwhile, many insurers perceive opportunities in responding to climate change. Green building construction investment is expected to exceed $\$ 12$ billion in 2008, while hybrid car sales grew by 38 per cent to 350,000 vehicles that year (almost 50 per cent year-over-year growth). ${ }^{27}$ The electric power industry foresees large investments in renewable technologies and end-use energy efficiency. ${ }^{28}$

Another indicator of this changing business environment is shareholder resolutions regarding climate change. The number of such resolutions hit an all-time record of 57 in 2008, as well as an all-time high of 25 per cent of shareholders voting for the resolutions. The number of subsequent withdrawals provides an indication that shareholders obtained their desired outcomes (Figure 2).

Such resolutions have been filed in various years with at least six U.S. insurance companies (ACE, AIG, Chubb, Cigna, Hartford, Marsh and Travelers). Shareholders were subsequently encouraged when ACE joined the EPA Climate Leaders programme and the CEO spoke publicly about the importance of addressing climate change. ACE also developed a broader set of products and services related to climate change. A resolution filed with Chubb Group was withdrawn after the company

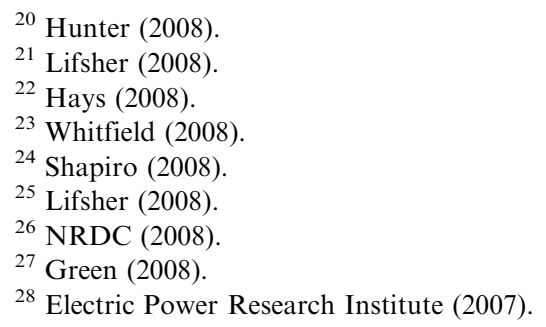




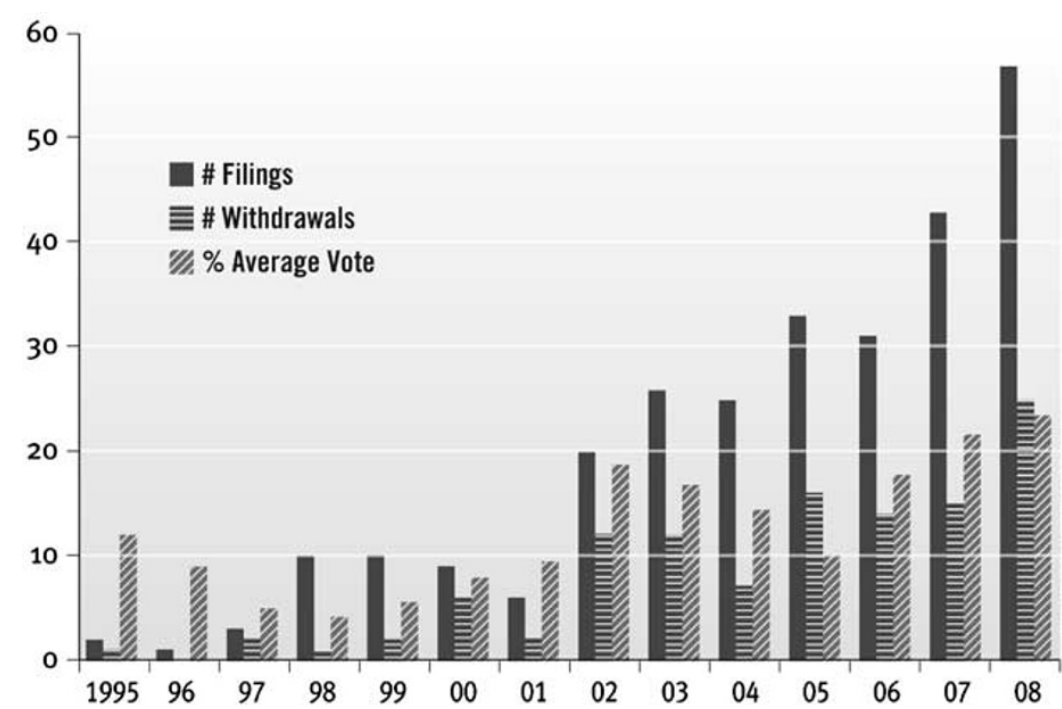

Figure 2. U.S. shareholder resolutions on climate change (Source: Ceres).

pledged to arrange a meeting with shareholders to discuss climate-risk issues. The resolutions filed with Hartford Insurance and Prudential Financial were withdrawn after the companies agreed to improve their public reporting and disclosure regarding the potential financial risks they face from climate change and strategies for mitigating those risks. The companies specifically agreed to respond to a climate-risk disclosure questionnaire sent to companies each year by the Carbon Disclosure Project (CDP).

To be sure, rising losses will create more demand for conventional forms of insurance, as well as new products such as weather derivatives and catastrophe bonds. This will be welcomed only if the changing risks can be understood and managed. There will also be demand for new forms of insurance, as well as for conventional insurance for new assets (e.g. green buildings or renewable-energy technology installations). ${ }^{29}$ Innovative products such as micro-insurance and new public-private partnerships will allow markets to grow to serve the billions of people in the developing world who currently lack insurance. ${ }^{30}$ Insurers seizing these opportunities will improve their market position. Note that micro-insurance products are not always designed or targeted with weather or climate factors in mind, although climate change will have consequences for most "lines" of micro-insurance.

With all of these factors in mind, insurance regulators under a National Association of Insurance Commissioners (NAIC) Task Force have met regularly in the U.S. to discuss climate change and issued a major white paper in 2008. The subject was among

\footnotetext{
${ }^{29}$ Marsh (2006).

${ }^{30}$ Mills (2004).
} 
330

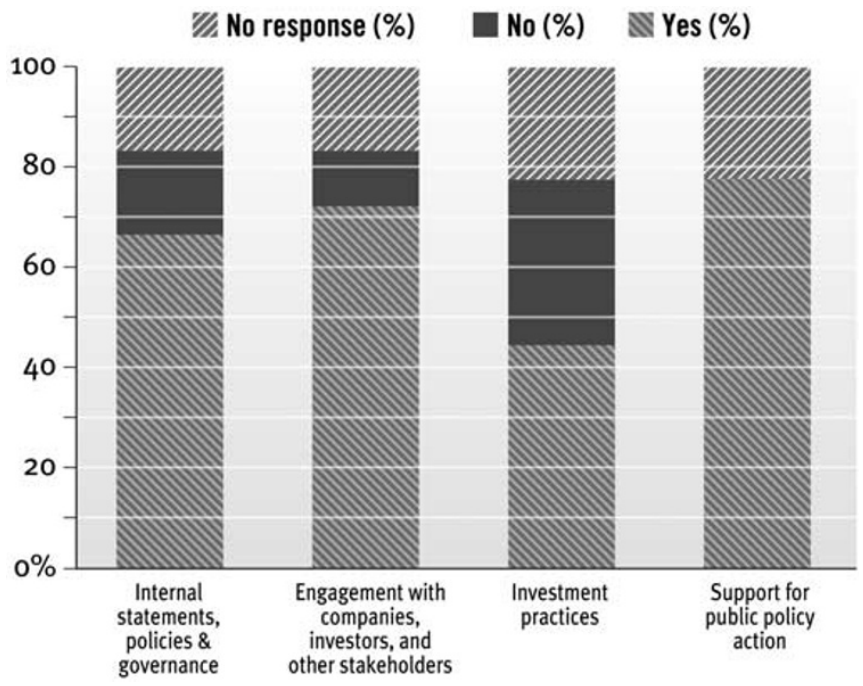

Figure 3. Strategic climate change activities among reporting insurers.

the top agenda items at the 2007 meeting of the International Association of Insurance Supervisors.

\section{From risk to opportunity}

Insurers and reinsurers along with trade allies and other members of their community (actuaries, ${ }^{31}$ brokers, agents, modellers, risk managers, asset managers and regulators) are increasingly seeing their industry as part of the solution through the creation of innovative products and services to promote emerging technologies and practices, while also harkening to their historical roots and devising new strategies for adapting to otherwise unavoidable impacts of climate change. The topic of climate change went from one that was rarely if ever addressed in the trade press just a few years ago, to a regular news item. As a reflection of the trends, in 2008 the three leading U.S. insurance trade journals (Best's Review, Business Insurance and National Underwriter) devoted special issues to climate change and the "greening" of insurance. In the past year, industry groups including the Association of British Insurers and CEA - the European Insurance and Reinsurance Federation - have called on insurers to more actively pursue climate change solutions to ensure the preservation of private insurance markets. ${ }^{32}$ In response, insurers have begun to

31 The Institute of Actuaries of Australia identified climate change as a key issue as early as 2003 (Gale, 2003). Actuary members of the General Insurance Research Organisation (GIRO) examined the increasingly problematic status of flood insurance in the U.K., noting the role of climate change (GIRO $\mathrm{n} / \mathrm{d}$ ). Two U.S. insurance actuarial organisations (CAS and SOA) have formed working groups on climate change.

32 CEA (2007). 


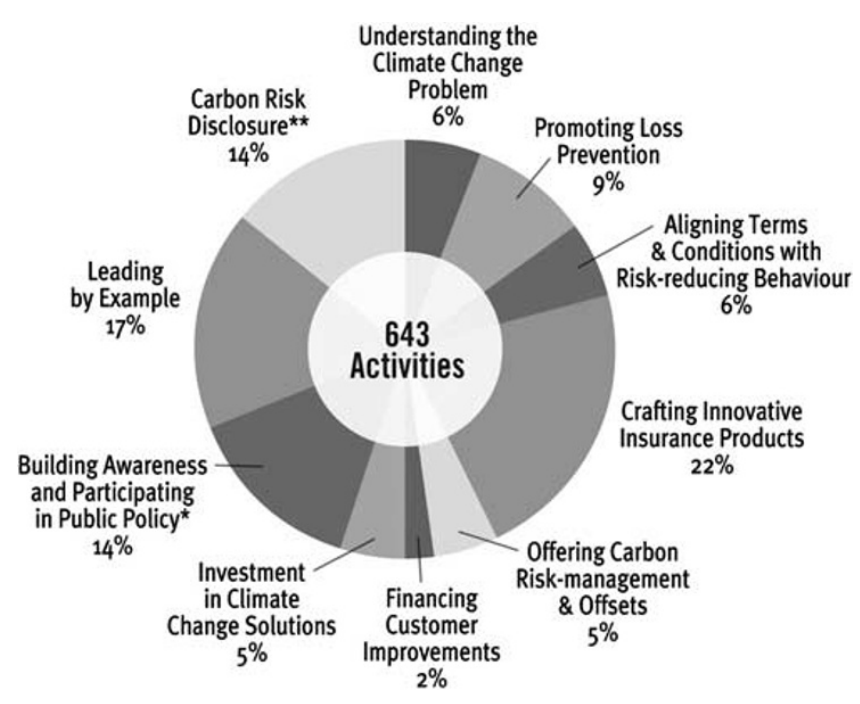

Figure 4. Prevalence of insurer climate activities.

institutionalise climate-risk practices for underwriting, investment and asset management (Figure 3).

The activities described in the remainder of this paper indicate the vast potential for insurers to introduce new climate-friendly products and services through their core business and to participate in the coming "green revolution" in the financial markets through their investments and asset management. A central challenge will be to ensure that these products are brought to scale in time to have a material impact on what is likely to be the biggest challenge facing the industry in its history.

We group the activities into 10 broad categories, as summarised in Figure 4, which we further break down into 34 specific classes of activity. These activities reflect a wide range of approaches to improving disaster resilience and adaptation to climate change, while reducing climate-related risks through strategies such as energy-efficiency programmes, green building design, sustainable driving practices, carbon-emissions trading and investments in emerging technologies. In some cases, the magnitude of progress or uptake can be quantified, as indicated in Figure 5. While this progress is encouraging, there is still little good data on how much traction these new activities have in the marketplace. Moreover, certain insurance lines have not been addressed (Figure 6).

\section{Methodology}

We gathered information from a variety of mostly primary sources for the period 1999 through 2008, for example, company news releases, corporate social responsibility (CSR) reports, filings with the CDP, corporate websites, insurance trade press, direct communications with insurers, scholarly journals and other reports. Initiatives that 


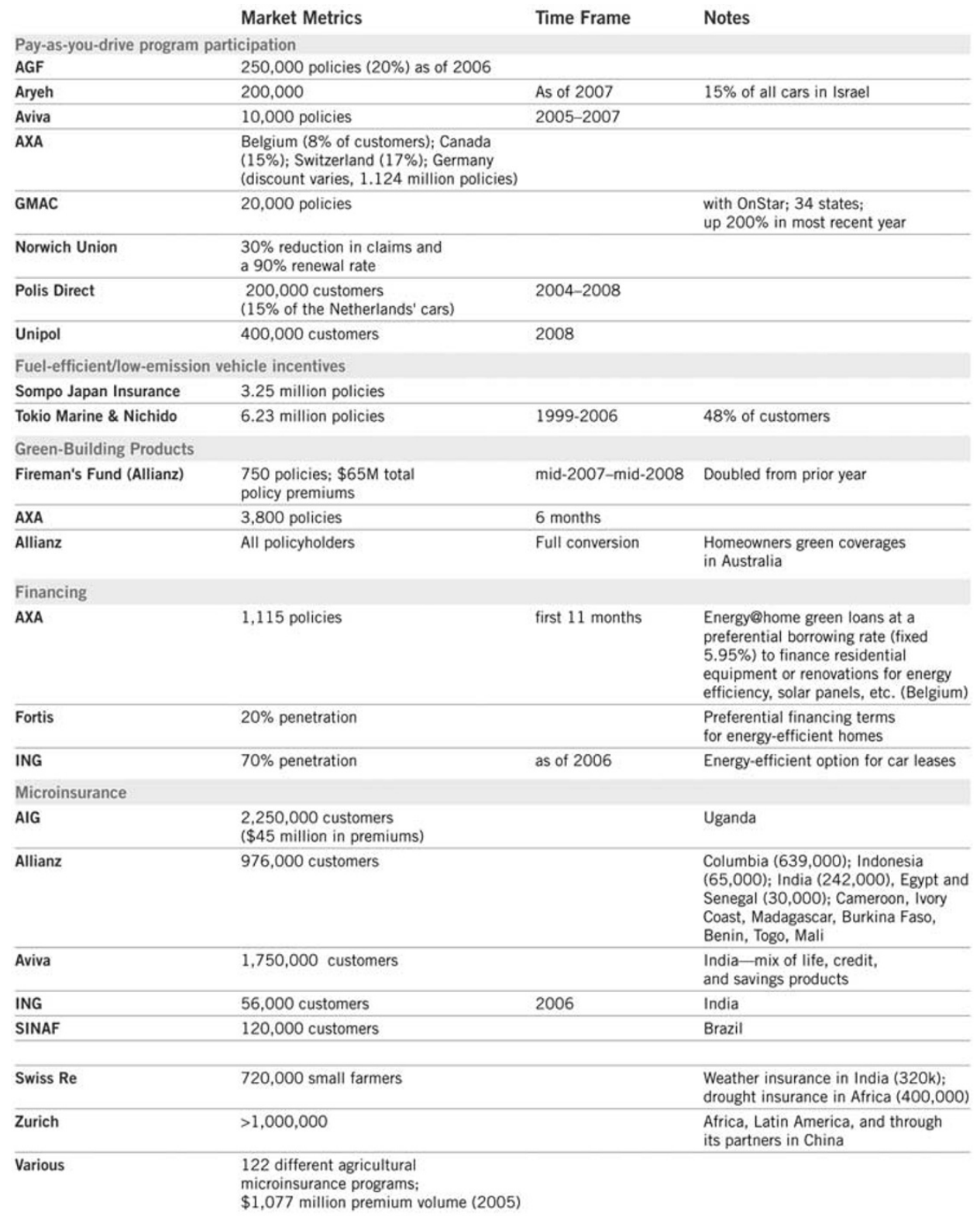

Figure 5. Market impact indicators for climate-friendly insurance products and services.

aggregate insurers (e.g. ClimateWise and the UNEP Finance Initiative) were also reviewed. To augment these data sources, we distributed a web-based survey to several hundred insurance industry contacts around the world, to major insurance trade journals and via the Climateandinsurance.org web portal. 


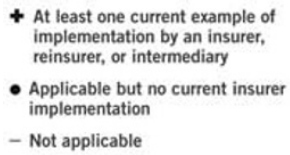

- Applicable but no current insurer implementation

- Not applicable

This chart maps the universe of possible climate-focused insurance product or service offerings, as well as other means of responding to climate risks. Activities represent emissions-reductions or customer-focused efforts to adapt to the effects of climate change. Pluses ( $\mathbf{+}$ ) represent cases where at least one such product or service has been offered. Dots (•) indicate a potential "fit" but for which there are no known examples in practice. No attempt has been made here to qualify or gauge the potential market size, affordability, or actuarial soundness of any given activity. The presence of a green diamond by no means indicates market saturation.

\begin{tabular}{|c|c|c|c|c|c|c|c|c|}
\hline Insurance Line & $\begin{array}{l}\text { Rebuild } \\
\text { more resilient } \\
\text { or "green" } \\
\text { after loss }\end{array}$ & $\begin{array}{l}\text { Bundled carbon } \\
\text { offsets }\end{array}$ & $\begin{array}{l}\text { Incentives for } \\
\text { low-emissions } \\
\text { or loss-resilient } \\
\text { profile }\end{array}$ & $\begin{array}{l}\text { Performance: } \\
\text { Energy savings } \\
\& \text { carbon } \\
\text { reduction risk }\end{array}$ & $\begin{array}{l}\text { Performance: } \\
\text { Energy } \\
\text { production } \\
\& \text { carbon } \\
\text { reduction risk }\end{array}$ & $\begin{array}{l}\text { Finance for } \\
\text { carbon- } \\
\text { reducing or } \\
\text { loss-resilient } \\
\text { improvements }\end{array}$ & $\begin{array}{l}\text { Advisory, } \\
\text { inspections, } \\
\text { or risk- } \\
\text { management } \\
\text { services }\end{array}$ & $\begin{array}{c}\text { Climate-risk } \\
\text { modeling } \\
\text { services }\end{array}$ \\
\hline \multicolumn{9}{|l|}{ Consumer Lines } \\
\hline Homeowners & + & + & + & $\bullet$ & + & + & + & - \\
\hline Auto & $\bullet$ & + & + & - & - & + & - & - \\
\hline $\begin{array}{l}\text { Accident \& Health } \\
\text { (individual) }\end{array}$ & - & - & $\bullet$ & - & - & - & - & - \\
\hline Life (individual) & - & $\bullet$ & $\bullet$ & - & - & $\bullet$ & - & - \\
\hline Travel & - & + & - & - & - & - & - & - \\
\hline Warranty & $\bullet$ & + & - & $\bullet$ & $\bullet$ & - & - & - \\
\hline \multicolumn{9}{|l|}{ Commercial Lines } \\
\hline $\begin{array}{l}\text { Industrial, energy } \\
\text { property }\end{array}$ & + & $\bullet$ & + & + & + & $\bullet$ & + & + \\
\hline Real Estate & + & $\bullet$ & + & + & $\bullet$ & $\bullet$ & + & + \\
\hline Offshore property & - & - & - & - & - & - & - & - \\
\hline Business Interruption & $\bullet$ & - & $\bullet$ & $\bullet$ & + & - & $\bullet$ & $\bullet$ \\
\hline Aviation & $\bullet$ & $\bullet$ & $\bullet$ & $\bullet$ & - & $\bullet$ & $\bullet$ & $\bullet$ \\
\hline Flood & $\bullet$ & - & $\bullet$ & - & - & $\bullet$ & $\bullet$ & $\bullet$ \\
\hline General Liability & - & - & + & - & - & - & $\bullet$ & $\bullet$ \\
\hline Inland Marine & - & $\bullet$ & + & - & - & $\bullet$ & $\bullet$ & $\bullet$ \\
\hline $\begin{array}{l}\text { Directors \& Officers } \\
\text { Liability }\end{array}$ & - & $\bullet$ & $\bullet$ & - & - & $\bullet$ & + & $\bullet$ \\
\hline Professional Liability & - & - & + & $\bullet$ & $\bullet$ & - & $\bullet$ & $\bullet$ \\
\hline Environmental Liability & $\bullet$ & - & + & - & - & $\bullet$ & $\bullet$ & $\bullet$ \\
\hline Ocean Marine & $\bullet$ & $\bullet$ & $\bullet$ & $\bullet$ & - & $\bullet$ & $\bullet$ & $\bullet$ \\
\hline Excess Casualty & $\bullet$ & - & $\bullet$ & - & - & $\bullet$ & $\bullet$ & $\bullet$ \\
\hline Workers Compensation & - & - & + & - & - & $\bullet$ & $\bullet$ & $\bullet$ \\
\hline Crop & $\bullet$ & $\bullet$ & $\bullet$ & + & - & $\bullet$ & + & $\bullet$ \\
\hline Standing Timber & $\bullet$ & $\bullet$ & $\bullet$ & $\bullet$ & - & $\bullet$ & $\bullet$ & $\bullet$ \\
\hline Travel & - & $\bullet$ & - & - & - & - & $\bullet$ & $\bullet$ \\
\hline Life (corporate) & - & $\bullet$ & $\bullet$ & - & - & - & $\bullet$ & $\bullet$ \\
\hline $\begin{array}{l}\text { Accident \& Health } \\
\text { (corporate) }\end{array}$ & - & - & $\bullet$ & - & - & - & $\bullet$ & $\bullet$ \\
\hline Commercial Auto & + & $\bullet$ & + & - & - & $\bullet$ & $\bullet$ & $\bullet$ \\
\hline Warranty & $\bullet$ & $\bullet$ & - & $\bullet$ & $\bullet$ & - & - & - \\
\hline Political Risk & - & - & - & $\bullet$ & + & - & $\bullet$ & $\bullet$ \\
\hline Asset Management & - & + & - & - & - & + & - & + \\
\hline
\end{tabular}

Activities Other Than Products \& Services

+ Contributing to climate science and modeling

+ In-house energy management and carbon offsets

- Carbon-offset projects (e.g. to obtain RECs, White Certificates, or for in-house offsets)

$+\quad$ Promotion of improved building codes, standards, etc.

+ Engagement in public-policy discussion

+ Conducting and fostering carbon-risk disclosure (possible customer service as well)

+ Filling coverage gaps for low-emission technologies, practices, or service providers (e.g. liabiity cover for energyservice providers; microinsurance in emerging markets; warranties for vehicles that use blended fuels, etc.)

Figure 6. "Green insurance" market map.

We rely primarily on self-reported information from insurers, which is not independently audited or verified. In certain areas, companies appear to be bundling/repackaging existing offerings, rather than truly innovating to fill coverage gaps or carefully tailoring coverage to the unique features of "green" technologies. 
The details often are not provided in cursory published materials or on company websites.

We apply various decision rules in determining if and how to include the activities of individual companies. To be included, the company had to be currently or historically conducting one or more of the types of activities described in this paper. An activity does not need to be currently in practice for it to be logged in our database. Prospective activities are generally not included, unless there is a firm publicly announced roll-out date. Multiple activities of a very similar nature are counted once (e.g. multiple reports on the implications of climate change, multiple years responding to a given call for disclosure, multiple efforts at reducing in-house greenhouse gas emissions, multiple years of CSR reporting, or more than one country in which microinsurance products are offered), while distinct but related activities (e.g. two separate innovative insurance products) are counted individually. Routine activities such as rationalising pricing, going paperless, encouraging generic disaster preparedness or conventional insurance of renewable-energy systems (which many insurers have done for decades), are not tabulated here as they are viewed as mainstream activities or not primarily motivated on the basis of responding to new climate change risks. Similarly, "passive" activities such as memberships in organisations (e.g. the U.S. Green Buildings Council) are notable, but are not logged as formal activities in our database. We do not include items that we deem to have a tenuous "green" value, for example insurers promoting GPS systems in autos but not accompanying it with mileagedifferentiated premiums.

\section{Advancing solutions}

Aside from the obvious risk of increased insured losses, the greatest peril comes in adopting the view that relegates climate change to a public relations and environmental issue that's best dealt with by delaying action, rather than taking the view of climate changes as a true business opportunity that demands action now.

\section{Howard Mills ${ }^{33}$ \\ Director and Chief Advisor, Insurance Industry Group Deloitte \& Touche U.S.A. LLP}

As the world's largest industry ${ }^{34}$ - generating just more than $\$ 4$ trillion in premium revenue in $2007,{ }^{35}$ plus another trillion or so in investment income, with core competencies in risk management and finance - the insurance industry is uniquely positioned to further society's understanding of climate change and advance creative solutions to minimise its impacts. Just as the industry has historically asserted its leadership to minimise risks from building fires and earthquakes, insurers have a huge

\footnotetext{
${ }^{33}$ National Association of Mutual Insurance Companies (2008).

${ }^{34}$ For sources, insurance.lbl.gov/opportunities/industry-size.xls.

35 Swiss Re (2008).
} 
opportunity today to develop creative loss-prevention solutions and products that will reduce climate change-related losses for consumers, government and themselves.

A number of major insurers are creating special cross-cutting teams or practices to formulate strategies and set priorities across their organisations. These activities are becoming more deeply rooted in the companies, rather than in public affairs or government relations. Zurich's Climate Office is embedded in the underwriting unit. ${ }^{36}$ Another illustration is given by Allstate, which in its response to our survey describes its activity as a team "that includes lead officers for all of the companies' major areas of responsibility (e.g. Human Resources, Real Estate and Administration, Procurement and Sourcing, Investments, Law and Regulation, Corporate Relations, Marketing, Product Operations, etc.)".

There is also a recent emergence of specialised "green" brokers, intermediaries and insurers. For example, the Environmental Transportation Association in the U.K. bundles carbon-neutrality for personal lines homeowner and auto insurance. Other examples are Green Insurance Co., Climatesure, Milemeter and Renewco Underwriting. On the other hand, some companies have appropriated green-sounding names (e.g. "Solar Insurance LTD") yet do not appear to offer corresponding products or services.

Insurers are "drilling deeper", filling coverage gaps, testing new delivery strategies and developing new partnerships with parties outside the insurance sector. We have identified a wide spectrum of insurance opportunities, with 643 real world examples from 244 insurers, reinsurers, brokers and insurance organisations from 29 countries. These entities collectively represent $\$ 1.2$ trillion in annual premiums and $\$ 13$ trillion in assets, while employing 2.2 million people. ${ }^{37}$ In addition to activities on the part of 189 insurers, eight reinsurers, 20 intermediaries and 27 insurance organisations, this report identifies 34 non-insurance entities that have collaborated in these efforts. Our database contains a total of about 5,300 data elements.

In the past 10 years, the number of climate-related activities has increased considerably, with eight times as many activities currently logged vs. the original compilation. ${ }^{38}$ This reflects not just an increase in activity across the industry but also within individual companies (from 1.2 to 2.6 over this period, with up to 25 in some cases). Figure 7 shows the multi-year trends for a number of categories: products and services, investment, climate disclosure and carbon-neutrality commitments.

In tandem with this growth, we have observed a continued proliferation of collaborations between insurers and non-insurance groups - ranging from energy utilities to foundations to governmental agencies - currently numbering 34 in all. Recent examples include the Earth Institute at Columbia University working with Swiss Re to implement satellite-based remote sensing in support of micro-insurance for small farmers in Africa and a joint project between Munich Re and the London School of Economics to refine our understanding of the economics of climate change.

\footnotetext{
${ }^{36}$ Zurich (2008).

${ }^{37}$ These values represent data for 65 of the 243 insurers, reinsurers and intermediaries catalogued in this report, albeit the largest ones.

38 Mills (1999).
} 


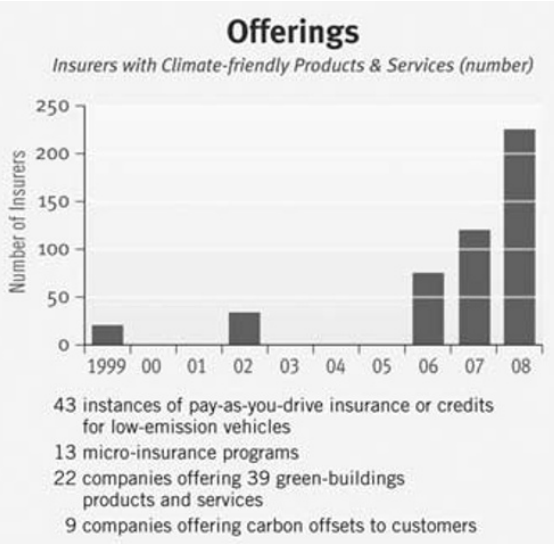

Disclosure

Insurer Responses to Carbon Disclosure Project Survey (number)

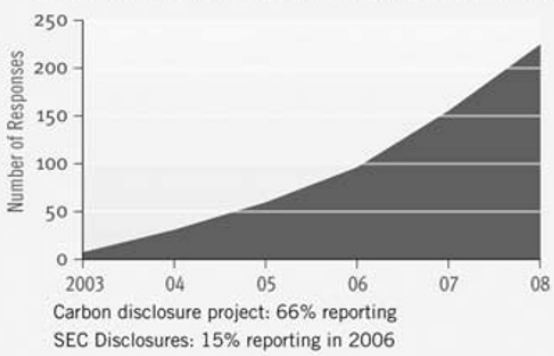

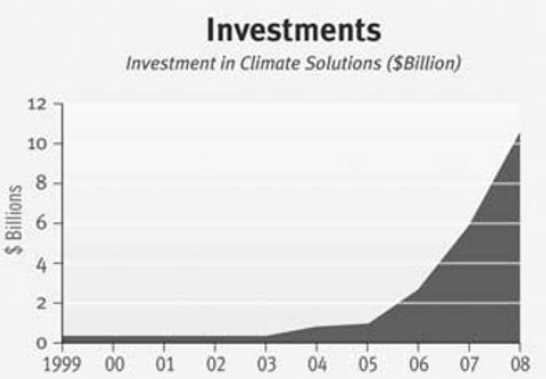

24 companies making direct investments

13 instances insurer financing of green projects

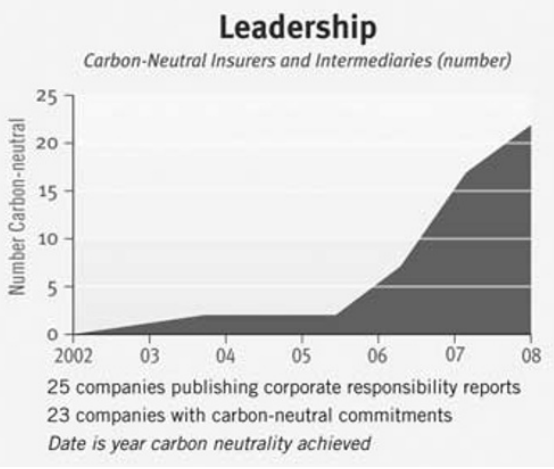

Figure 7. Trends in insurer climate change activities.

Other partnerships have been initiated with the Asian Development Bank, The Heinz Centre, the International Finance Corporation and RAND.

Property-casualty insurance companies are driving the majority of the activity (homeowner, commercial and auto), with life-health companies lagging far behind. Within the property-casualty segment there is still considerable room for improvement and we have seen no activity on the part of certain segments (e.g. offshore property, aviation, ocean marine or standing-timber insurers). The past year has witnessed a very significant increase in activity on the part of liability insurers, raising the possibility that more insurers might willingly assume the responsibility of climaterelated litigation costs borne by their policy-holders. There has been relatively minor activity in the travel, warranty, industrial, business interruption, inland marine, workers' compensation, crop, professional liability and commercial auto insurance markets.

Western European insurers have the deepest history with these initiatives and some of the more comprehensive strategies can be found there. Considerable creativity and innovation has emerged from the United States, with 37 per cent of all activities logged in our database (the most of any country). There is somewhat more activity in 
Europe as a whole (47 per cent) than in North America (40 per cent). Although Asian insurers have been first movers in many areas, few new initiatives have come to our attention there. Some Australian insurers are quite active on a variety of fronts. In every country, leadership is demonstrated primarily by larger companies. Insurance brokers - primarily in the United States - have also shown significant leadership as well.

In addition to the raw growth in the number of activities, we have observed sophisticated and targeted product design and initiatives more directly focused on spurring the use of new technologies and practices to combat climate change. Some insurers have ventured considerably outside of the proverbial "box", as exemplified by Progressive's \$10-million X-Prize for efficient automobile design.

We also observe a number of more fundamental strategic trends. These include increased engagement of trade allies and a considerable increase in the engagement of insurance regulators, particularly in the United States with the release of a major policy paper by the NAIC and follow-on work concerning climate-risk disclosure. Insurers also have ramped up their engagement with the public policy discussion about responses to climate change at the national and international levels. As expert messengers on risk, insurers are assuming an important role in alerting policy-makers to the need to proactively deal with climate change at the national and global levels. As major players in financial markets, insurers are in the forefront in capital formation and investment in new climate-friendly technologies.

Insurance trade organisations remain relatively inactive on climate change (compared to their most engaged member companies), with a few notable exceptions. The Association of British Insurers has become an important hub of activity in the U.K. and the U.S.-based National Association of Mutual Insurance Companies operates a vibrant portal on climate change information and related industry news and the Reinsurance Association of America issued its first climate change policy in 2008. The Insurance Information Institute is facilitating integrating catastrophe (CAT) and climate modelling.

There is considerable and well-founded interest in the materiality of these efforts to the broader insurance business and the degree of "traction" being obtained by this proliferation of new green insurance products and services in the marketplace. While in most cases, the efforts have moved well beyond public relations, scant information is available on market penetration. This paper identifies more than 18 million policies that have been created by these initiatives, the largest category being incentives for low-emissions vehicles followed by micro-insurance in the developing world. While the full scale of market penetration is not known, it no doubt represents a tiny fraction of global policies, suggesting that the overall insurance market remains considerably undeveloped in terms of climate change products and services.

In the following sections, we provide a brief synopsis of activity in each of 10 major categories of possible insurer action. More in-depth discussion is provided in a background report. ${ }^{39}$

\footnotetext{
${ }^{39}$ Mills (2009).
} 


\section{Understanding the climate change problem}

Climate change is clearly one of the most critical issues of our time and an area of vital ongoing scientific investigation. ${ }^{40}$

Karen Clark

Founder, Applied Insurance Research

The insurance industry has a history of helping society understand and adapt to emerging risks. Climate change is no exception and insurers are beginning to apply their expertise in data collection, catastrophe modelling and risk analysis to better track trends and define the problems posed by climate change and point towards solutions for both the industry and society at large. Insurers also are partnering with the scientific community to perform basic research and help build forward-looking risk models that take climate change into account. Insurer's traditional modelling techniques are still ill-suited for understanding the implications of climate change and fine-grain loss data are incomplete and under-utilised in understanding the trends.

Insurers' involvement has ranged from working directly with IPCC (Munich Re, Tokio Marine Holdings, RMS, CGU), to sponsoring expeditions to study the thickness of the polar ice cap (Caitlin Group). At least half a dozen insurers are working with CAT modelling firms to help better reflect climate change in their analyses. Such modelling exercises also have produced very policy-relevant analyses of the relative benefits of investments in efforts to reduce greenhouse gas emissions vs. adapting to climate change. Trade associations such as the Association of British Insurers and the Insurance Information Institute have participated in these efforts.

\section{Promoting loss prevention}

The Hartford will strongly advocate for better land use planning as well as for improved and more vigorously enforced building standards. The Hartford will continue to oppose subsidies and other incentives that promote development in areas most exposed to natural disasters.

Hartford Financial, CDP Response, 2007

Managing risks and controlling losses is central to the insurance business and is evident in the industry's history as founders of fire departments and advocates for building codes or auto safety. Insurers are increasingly engaging in the process of adapting to climate change, but their influence at present is dominated by reactive approaches. While their primary focus has been on financially managing their own risks (through exclusions, price increases, derivatives, etc.), physical risk management on behalf of customers is receiving renewed attention and could play a large role in

\footnotetext{
${ }^{40}$ Insurance Journal (2008).
} 
helping to preserve the insurability of coastal and other high-risk areas. Improved building codes and land-use management are important starting points, but insurers and others face many barriers. There are isolated examples of more proactive engagement, such as large-scale reforestation of mangrove forests by insurers on the Pacific Rim. Insurers are increasingly finding value in a whole genre of energy-efficient and renewable-energy technologies that also make infrastructure less vulnerable to insured losses and in improved management of forests, agriculture and wetlands. Insurers are gradually finding a role in helping to understand the risk profiles of "green" technologies and practices. ${ }^{41}$ The scale and breadth of insurer efforts in all of these areas remain extremely modest in the context of their overall business operations.

\title{
Aligning terms and conditions with risk-reducing behaviour
}

"Green" customers tend to present better risk profiles, which can be translated into lower rates.

\author{
AXA \\ Response to 2006 Carbon Disclosure Project Survey
}

New kinds of insurance terms and policy exclusions - designed to instil behaviours that reduce greenhouse gas emissions, as well as appropriate efforts to prepare for the impacts - are beginning to emerge in the face of climate change. Pay-as-you-drive insurance products have now been offered by at least 26 insurers around the world with discounts up to 60 per cent in recognition of the link between accident risk (as well as energy use) and distance driven. In another example, potential liability of corporate directors and officers for their actions (or lack of action) regarding climate change risks has only recently been reflected in insurance policies. Conversely, customers with a tendency to reduce climate vulnerabilities (e.g. drivers of hybrid cars or operators of green manufacturing operations) are increasingly being seen as "good risks" and are being rewarded accordingly with lower premiums by 17 insurers. Fireman's Fund launched the first replacement-upgrade product for hybrid cars. In the first example of a marine insurance product, Travelers offered a 10 per cent premium discount for hybrid-electric boats and yachts.

Many more insurers are recognising a correlation between sustainable practices and reduced risk (a "halo effect"), in some cases giving discounts on workers' compensation and environmental coverages for qualifying customers. However, more data and research are needed to sufficiently understand and fully reflect the effect in product design.

\section{Crafting innovative insurance products and services}

To take advantage of the opportunities and respond to risk attendant to climate change, certain sectors of the economy must adapt or reinvent their business

\footnotetext{
41 Taylor (2008), Marsh (2008).
} 
models. Proper enterprise risk management dictates a re-evaluation of existing risk management tools in response to this "green" paradigm shift. Insurance is one of those tools that can be used to both achieve competitive advantage and corporate social responsibility - if properly leveraged. ${ }^{42}$

Lindene Patton

Climate Products Officer, Zurich Financial Services

In order to avoid the worst physical impacts of climate change, the world will need to dramatically transform the way it produces and consumes energy. Insurers recognise an enormous opportunity to develop new profit centres by providing innovative products and services (or extending existing policies) for energy users or providers of clean energy services. Insurers and catastrophe modellers can also tap their core competencies to offer new services to assess and mitigate climate risks.

Insurers are offering green buildings products and services, including products and services especially designed for new green buildings and upgrades to green traditional buildings either following a loss or in the course of normal renovations. The sophistication and specificity of existing products is increasing - 22 companies have collectively offered 39 related products or services.

Almost all of the climate-related innovations in liability insurance for directors and officers, political risk, professional liability and environmental liability have appeared in the past year. Both Zurich and Liberty Mutual launched products specifically designed to cover boards of directors in the event of climate change litigation, a significant development given pending lawsuits that could allocate significant costs to major emitters of greenhouse gases.

In 2008, for the first time, insurers launched products to manage diverse risks from CCS projects, while publishing research helping to understand the limits of insurability. Products offered cover several types of risk unique to CCS (the process of capturing hazardous carbon dioxide at the source of the pollution and injecting it into geological formations beneath the surface of the Earth and storing it over the long term). The controversial process - still not demonstrated at full scale - is gaining significant interest as a solution to enable continued use of carbon-intensive energy such as coal. The technological enthusiasm for this approach has thus far eclipsed the effort spent on technical and financial risk assessment. One insurer noted that "the public dialogue to date has focused on the technology and has not yet focused on the business risk models in a disciplined way because not all the correct stakeholders are at the table" 43 and expressed concern that subsidies and public indemnity of CCS projects could mask or even magnify CCS risks, while creating complacency and moral hazard. ${ }^{44}$ Insurance for CCS projects will add to the technology's cost and thus influence the relative cost-effectiveness and competitiveness of this carbon management strategy vs. that of others. The insurance risks of CCS

\footnotetext{
42 Zurich (2008).

${ }^{43}$ Patton (2008a).

${ }^{44}$ Patton (2008b).
} 
include unintended environmental impacts such as the contamination of drinking water. Also a concern is injury or death to humans or animals if the captured gas leaks in sufficient quantities. ${ }^{45}$ Engineering risks such as vapour cloud explosion or catastrophic failure of the cryogenic air separation unit also present potential problems. ${ }^{46} \mathrm{CCS}$ projects would have a particularly complex life cycle, including political, financial and regulatory risks before project start-up; site identification and development; at the point of capture; during carbon transport; during the citing and sequestration process; during closure of injection points; and during the stewardship period. ${ }^{47}$ Containment will have to span centuries, which presents long-term risks that private insurers would presumably prefer to defer to governments (similar to the insurance provided by governments for nuclear power plants). Since part of the business proposition of CCS is to capture "carbon credits" for carbon dioxide not released to the atmosphere, the same performance and liability risks apply to CCS as discussed elsewhere in this report as they relate to other strategies for trimming emissions.

Climate-related micro-insurance, which provides coverage for low-income populations without access to traditional insurance, is reaching a greater number of policy-holders than most climate-related products in the traditional market. This paper identifies micro-insurance products covering about 7 million policy-holders. Many of these products respond to climate-linked vulnerabilities such as food and water shortages in rural areas of South America, Africa and Asia; much of this market activity tends to be driven by European insurers.

Renewable energy has seen a flurry of activity, but most appears to be little more than bundling/repackaging of existing offerings, rather than purely innovating to fill coverage gaps or carefully tailoring coverage to the unique features of these technologies. Coverages for energy providers faced with less-than-anticipated solar or wind energy production have been brought to market by AXA, Munich Re, Navigators, Sompo Japan and Tokio Marine Holdings.

\section{Offering carbon risk management and carbon reduction services}

Project portfolio underperformance and counterparty risks have dramatically increased in the last 6 months and buyers, lenders and investors in emission reduction projects are concerned about their money - compliance buyers about their license to produce! ... At project level in developing countries and emerging markets there is a lack of risk management and insurance coverage to protect the investments needed to fight global climate change. ${ }^{48}$

Dirk P. Kohler CEO, Carbon Re

\footnotetext{
45 Wilson et al. (2007).

${ }^{46}$ Carroll and Seakins (2008).

47 Trabucchi and Patton (2008).

${ }^{48}$ Insurance Times (2008).
} 
Climate change has become a risk to be managed and insurers and brokers are well positioned to develop and offer such expertise. Included in this is managing the risks associated with responses to climate change.

A small but increasing number of insurers aspire to spur the burgeoning market for carbon trading by providing mechanisms for participants to better manage carbon risk. There has been a recent burst of activity involving bundling carbon offsets with insurance products, particularly automobile and travel insurance. Insurers are becoming involved in providing property and liability insurance for carbon-reduction capital projects, as well as consultative services in designing and managing such projects so as to maximise their technical and financial upside. Services can take the form of new business lines in energy auditing, retrofit evaluation, installation and management, as well as a host of quality-assurance services (e.g. commissioning) that manage the performance risks of energy-saving and carbon-offset projects.

Insurers have also begun to pay attention to the quality of carbon-offset approaches. Quality control in carbon-offset projects has been encouraged through the reward of reduced related insurance premiums projects that are certified by the Gold Standard rating service.

\section{Financing climate-protection improvements}

Climate change creates significant costs for the financial industry. In the interest of our clients and shareholders we are obligated to take these risks into account when making decisions on insurance underwriting, investments or lending credit. ${ }^{49}$

Joachim Faber

Allianz SE Board Member and CEO of Allianz Global Investors

Insurers, especially those associated with banking operations, are in a position to engage in financing customer-side projects that either improve resilience to the impacts of climate change or contribute to reducing emissions. In some cases, this takes the form of secondary credit support. Only in the past two years have insurers ventured into this area - often building insurance products with financing - which is one of the least developed in our entire inventory.

Fortis has offered financing for fuel-efficient cars coupled with discounted insurance; KBC offers preferential terms on "green" home-improvement loans. AXA has bundled insurance and financing for solar panels and home improvements. Fortis, HSB, ING and AIG have provided commercial financing or credit support for large-scale energy-efficiency, renewable-energy and other types of carbon-saving projects.

\footnotetext{
49 Innovest (2007).
} 


\section{Direct investment in climate change solutions}

[O]ur wind energy investments are a case where we are making money by doing good. We're investing in a cleaner environment and earning a premium return in the process. ${ }^{50}$

Frank Gould, Head of Prudential's Structured Transactions Group

Insurers are among the most significant players in financial markets, with \$16.6 trillion in financial assets as of $2005 .^{51}$ Similar to other large investors, insurers are beginning to realise that climate change presents significant risks and opportunities on the asset side of their organisations. We have logged a total cumulative value of $\$ 11$ billion in climate-friendly investments from 15 of the leading companies (total investment is not known) (Figure 7), as well as significant examples of "green" real estate development and management. While this level of activity is nearly double that observed in last year's report, it is a modest portion of all investment in this space and a vanishingly small part of insurers' own portfolios. European insurers remain far ahead of their American and Asian counterparts in investing in climate solutions and setting voluntary standards for sustainable investments, with the notable exception of AIG as a leader among American insurers. Many have expressed concern about the vulnerability of insurers' assets to the effects of climate change, but data has not been forthcoming on whether or not insurers have made material efforts to rebalance their portfolios.

\section{Building awareness and participating in the formulation of public policy}

An integrated climate change strategy needs to be implemented coherently across national, devolved, regional and local boundaries and it needs to maximise the synergies between emissions reduction (dealing with the causes of climate change) and climate risk management measures (tackling the consequences of climate change). ${ }^{52}$

Association of British Insurers Consultation on Proposals for a Scottish Climate Change Bill

Insurance is often thought of as a tool to be brought into play only after a loss has been sustained. In actuality, insurers regularly engage in proactive public policy discussions, whether concerning terrorism, public health or natural hazards. It is in the business interest of insurers to support public policies that reduce and make risks more predictable. In the case of climate change, society can prevent losses, both by trimming the emissions that cause climate change and adapting to unavoidable

\footnotetext{
${ }^{50}$ Prudential (2008).

${ }^{51}$ UNEP (2007).

52 ABI (2008).
} 
impacts. A number of excellent examples exist, but industry-wide engagement in these pursuits is nowhere near its potential. The UNEP Finance Initiative and ClimateWise have become very significant activities in this respect, the former involving 33 insurers and the latter involving 41 insurers and associations. AIG and Marsh participate with companies such as ConocoPhillips and Duke Energy in the U.S. Climate Action Partnership, which call on the United States to establish mandatory targets to reduce greenhouse gas emissions by $60-80$ per cent over several decades. Beyond this, activity in the United States remains muted.

\section{Leading by example}

If insurers publicly advocate for and develop products that influence change in consumer behaviours, then sure enough, the insurance industry will appear to be in the vanguard of the environmental movement. The industry should not be afraid to be bold on this issue. In fact, this might just be the perfect opportunity for the insurance industry to demonstrate how it really does advance the interests of all of us ahead of its own, narrower commercial interests.

\section{David Gambrill, Editor, Canadian Underwriter ${ }^{53}$}

Leadership by example - "walking the talk" - is one of the most potent means of effecting change, while managing reputational risk. Insurers are among the early adopters of CSR reporting - with 25 examples to date - as well as efforts to reduce their own carbon footprints. While insurers are not major emitters of greenhouse gases, the energy used by their extensive real estate holdings and employee travel is more significant than casual observers might expect. We estimate that the global industry emits about 12 million metric tons of carbon dioxide equivalent each year, which is equivalent to the emissions from 2.5 million U.S. cars, four large electric power plants or 60,000 train cars full of coal. This includes most forms of energy use, but not indirect emissions from business operations (e.g. those associated with paper consumption, supply chains or employee commuting transportation).

Insurers are increasingly recognising the importance of addressing their own carbon footprints. We found a remarkable 14-fold variation between the highest and lowest emitters (on a per-dollar basis) (Figure 8). Seventeen insurers and reinsurers and six brokers have achieved carbon-neutrality and others have public commitments to attain carbon-neutrality at a specific point in the future.

Many insurers tout their in-house energy/carbon management efforts, some of which are significant but many are quite modest, including that of overlooking the energy-intensive activities associated with information technology. Carbon accounting methods are hardly standardised within the industry - or in CDP reporting - which confounds efforts to benchmark and track progress.

\footnotetext{
${ }^{53}$ Gambrill (2007).
} 


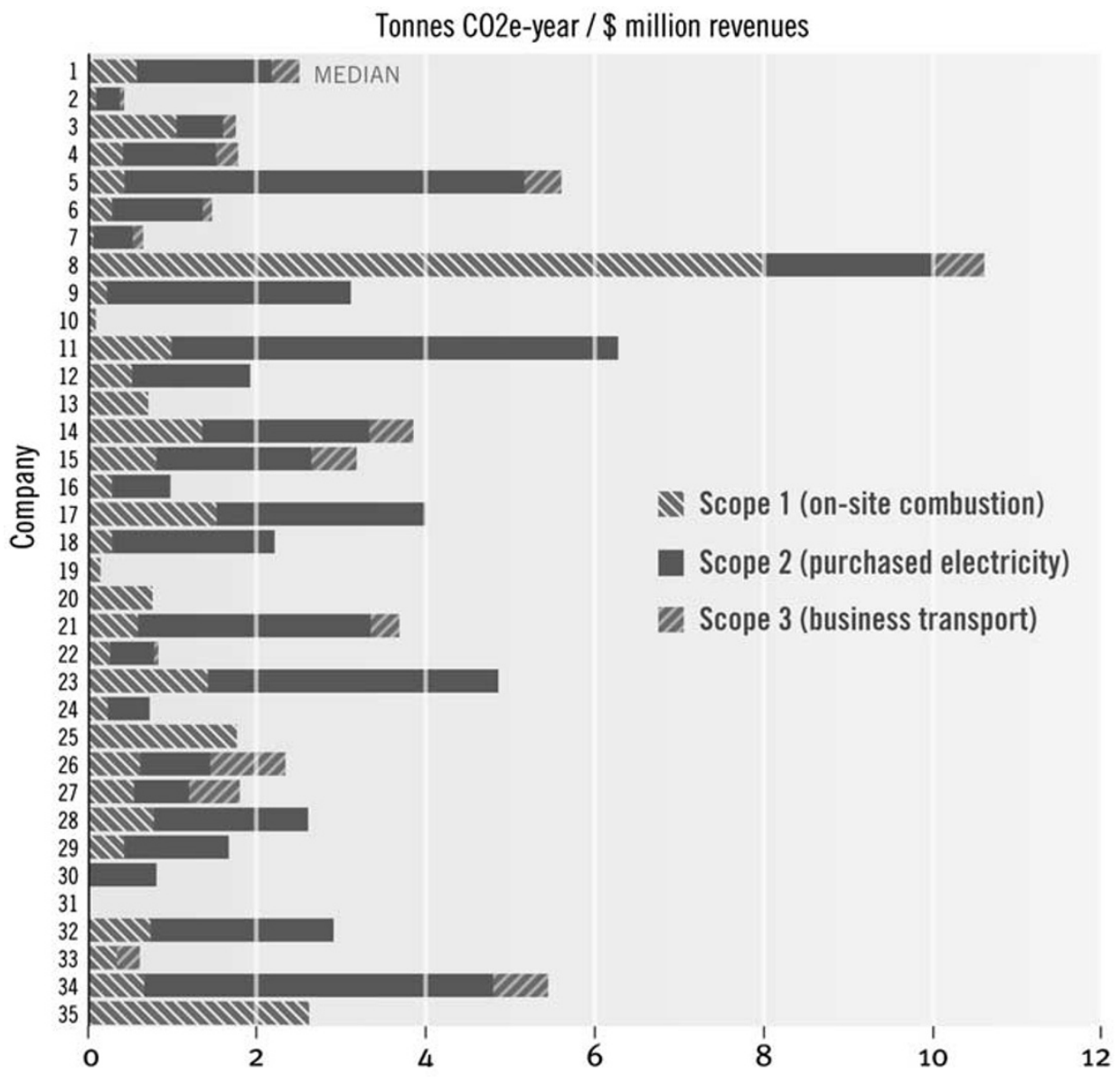

Figure 8. Greenhouse gas emissions vary widely among insurers.

\section{Climate risk disclosure}

A disclosure for climate change risks is necessary because of the potential magnitude of climate change on insurer solvency and insurance availability and affordability across all major categories of insurance: property casualty, life and health. ... Such responses will enable regulators to follow up with questions as necessary and will allow investors and consumers to incorporate additional information into their investment and purchasing decisions.

National Association of Insurance Commissioners Climate Risks Disclosure Proposal (15 August 2008, draft)

Assessing and disclosing climate risks enhances the ability of insurers to evaluate the impacts of climate change on their business and take steps to address the associated 
challenges and opportunities. Meanwhile, disclosure builds confidence and enables consumers and investors to gauge whether to purchase a policy from or invest in a particular insurance company. It also helps regulators to meaningfully monitor insurers' financial conditions and the progress they are making towards managing climate change risks. Insurers have made such disclosures in documents to federal regulatory agencies such as the U.S. Securities and Exchange Commission and have made such information publicly available in response to formal requests from institutional investor groups, the largest example of which is the annual voluntary call by the CDP. Until recently, U.S. insurers lagged far behind those domiciled in other countries; now, however, average response rates are around 65 per cent. The U.S. NAIC has adopted a mandatory climate-disclosure process, which was strongly resisted by some industry actors.

\section{Climate change liability: emerging risks, emerging opportunities}

Business leaders are also concerned about emerging environmental liabilities, in the context of growing scrutiny of corporate environmental performance and fears about the impact of climate change and industrial pollution.

$$
\text { Lloyd's of London }{ }^{54}
$$

While much has been said on the issue of property losses from climate change, it is becoming increasingly clear that losses arising from the causes and impacts of climate change, as well as the emerging responses to it, will also pierce the liability lines. The numerous potential triggers include:

- responsibility for:

- abrupt impacts of extreme events linked to climate change;

- gradual impacts such as increased mould losses from warmer and wetter climates and flooding; 55

o consequences of climate-linked events (e.g. waste spills); ${ }^{56}$

- failing to adapt adequately to climate change impacts. ${ }^{57}$

o demands for compensation for prudent adaption costs;

- political risks;

- poor corporate governance and failure to fulfil fiduciary duties in light of climate change risks and opportunities;

- professional liability associated with implementation of new technologies;

- contract performance in carbon-offset or energy production/saving projects and carbon credit non-delivery;

- false advertising ("greenwashing");

\footnotetext{
${ }^{54}$ Lloyd's of London (2008).

55 Lavoie (2006).

56 Maier (2006).

${ }^{57}$ Lenckus (2008b).
} 
- disinformation/fraud;

- inadequate fiduciary responsibility (investment choices);

- worsening roadway risks affecting vehicle liability losses.

Insurers are seen to be assuming certain risks in this domain (e.g. under pollution liability covers) for which they are neither collecting adequate underwriting information or premiums, nor having adequate surplus. ${ }^{58}$ Meanwhile, professionals working in this sphere need to be attentive to changing standards of care, as new data, methodologies and technologies become the norm. ${ }^{59}$ In one example, the first litigation concerning a green building appeared in 2008, invoking questions of project quality and delivery of agreed performance. ${ }^{60}$ Similar risks - perhaps manifesting as product liability claims - will be faced by appliance and equipment manufacturers, for example for meddling with energy-test procedures used for product labelling. An example of the latter took place in $2008^{61}$ when a manufacturer's product failed to meet its promised energy-savings. The manufacturer has promised to refund all purchasers for electricity not saved and the product will be removed from the EnergyStar Program. ${ }^{62}$

An array of insurance lines and customer segments can be affected by liability claims as well as defense costs ${ }^{63}$ Aon discusses the hypothetical case of

the permanent loss of ecological assets as a result of irreversible changes caused by climate change. This might involve ski resorts in Colorado bringing claims against power generators because there is no longer enough snow to operate on a normal schedule, fishermen filing claims against industrialized nations because species they harvested are no longer present due to warmer ocean temperatures and Alaskan natives filing claims against automobile manufacturers alleging that global warming due to $\mathrm{CO}_{2}$ emissions have reduced ice floes making hunting more dangerous. ${ }^{64}$

More than a quarter of corporate board members surveyed believe that climate change could trigger a major wave of liability claims in the next 5 years ${ }^{65}$ and several other risks that could be compounded by climate change received even higher scores. About half of the board members discuss climate change in the boardroom, or think it should be a topic of discussion. The level of perceived risk compares to that of terrorism, pandemic, general environmental risks and product liability.

Indeed, some such losses could manifest far in advance of physical impacts, as parties bring claims against emitters and other groups. About 100 such cases have been brought to date. ${ }^{6}$ Suits do not always seek economic damages. For example, a

\footnotetext{
58 Idem.

${ }^{59}$ Sandridge (2008).

${ }^{60}$ Del Percio (2008).

${ }^{61}$ Consumer Reports (2009).

${ }^{62}$ Bhambhani (2008).

${ }^{63}$ Ross et al. (2007).

64 Aon (2007).

${ }^{65}$ Lloyd's of London (2008).

${ }^{66}$ Arnold and Porter (2008)
} 
judgement against ConocoPhilips required energy-efficiency upgrades, etc. However, insurers will incur defense costs irrespective of the remedy sought or the outcome of the case.

Several universities (Stanford, U.C. Berkeley, U.C. Los Angeles) have dedicated entire symposia to the questions of climate change and the law, including the implications for insurers. Lloyd's of London's latest 360 report surveyed the issues. Munich Re held a workshop on the topic at its North America headquarters in 2008. ${ }^{67}$ All major insurance trade journals ran cover stories on the issue, which is perceived to become more tangible given the high degree of certainty regarding the human influence on climate change as reported in 2007 by the IPCC. Liabilities associated with climate change and its responses were featured in a series of papers in Business Insurance in late 2008.

Insurance brokers are among the first to envision a role for new insurance products, drawing analogies to asbestos, tobacco and mould. Willis has noted:

To stay competitive, corporations with any sort of greenhouse gas emissions will soon have little choice but to integrate exposure to global warming liability into their risk management programs. Insurance products being developed in the market are likely to play an important part in these programs. ${ }^{68}$

As one indicator of the rising concern, shareholder resolutions were filed with 57 U.S. companies in 2008 (Figure 2), almost half of which were withdrawn after the companies responded. Those that were voted on received a nearly 25 per cent rate of support, which is significant given the extent of non-voting, automatic voting with management and the high concentration by major shareholders.

Liabilities also are associated with certain emerging responses to climate change, particularly CCS, and nuclear power. For the latter, questions of waste and public health have not been resolved and the spectre of weapons proliferation looms large when some estimates call for 4,000 new nuclear power plants around the world in order to curb greenhouse gas emissions. ${ }^{69}$ The chair of a Nuclear Regulatory Commission Panel testified in spring 2008 that the U.S. proposals "will create significant technical and financial risks by prematurely narrowing technical options". 70 Even "green" responses can bring unintended liabilities, for example claims about performance or product attributes that are not borne out. ${ }^{71}$

In response to the perceived risks, a number of insurers have created new products and services (mostly in the 2007-2008 period) to help customers proactively manage the risks. ${ }^{72}$ Included are a host of mileage-based insurance products, which help stem auto-liability losses as well as property losses.

\footnotetext{
${ }^{67}$ Munich Re (2008b).

${ }^{68}$ Orleans (2007).

${ }^{69}$ Kramer (2008).

70 Ibid.

${ }^{71}$ Patton (2008a, 2008b).

72 Mills (2009).
} 
In addition to customer-side liability risks, insurers face their own exposures. Claims could arise from assertions that insurers are not responding in ways that adequately protect customers or fulfil fiduciary duties to shareholders (in underwriting or asset management), as well as the types of "wind vs. water" challenges that arose particularly strongly in the wake of Hurricane Katrina. Claims also could assert that the availability and pricing of insurance encouraged mal-adaptation, that is excessive exposure in at-risk areas. Lastly, while not industrial-scale emitters, by virtue of owning and occupying buildings and operating in a travel-intensive industry, insurers are directly responsible for material greenhouse gas emissions. As described above, more than 100 insurers have accepted invitations to voluntarily disclose their climate risks; doing so is one manner of managing those risks. Insurers also have participated actively in capitalising emerging carbon-free technologies and industries and have been outspoken in their calls for public policy reform to address climate risk.

\section{The intrinsic role of regulators: examples from the United States}

Nearly anything that is insured - property, crops and livestock, business operations or human life and health - is vulnerable to weather-related events ... State insurance regulators are aggressively moving forward to influence greater industry attention and action relative to climate change-related risk. ${ }^{73}$

Sandy Praeger,

President, National Association of Insurance Commissioners

Insurance regulators have two overarching and interrelated goals: to maintain the availability and affordability of insurance for customers and to guard against insurer insolvency. While there are many appropriate roles for regulators in climate change vulnerability assessment, ${ }^{74}$ we focus here on their role in enabling the types of traditional and innovative responses described in this report. ${ }^{75}$

Regulators have a responsibility to see that rates are adequate and that stateoperated insurance pools have sufficient capacity to pay losses. In a changing climate this will, among other things, require consideration of the ability of catastrophe models to account for climate change.

Where insurers desire to provide differentiated premiums or financial incentives to encourage risk-reducing behaviour, it is often necessary to demonstrate to regulators that there will be an offsetting reduction in losses. Reviews vary from state to state and are negligible in some cases while quite thorough in others. Insurers interviewed by the Iowa Department of Natural Resources cited difficulties in gaining regulatory approval for premium credits as a key barrier. ${ }^{76}$ In the United States, insurers are essentially free to develop new fee-based services outside of the insurance core

\footnotetext{
73 NAIC (2008).

${ }^{74}$ Mills et al. (2006).

75 Mills (2007).

${ }^{76}$ IDNR (2000).
} 
business, such as the risk assessment and management services for carbon-offset projects.

For insurers to engage in research and development, or equity/venture-capital investments in "climate-friendly" companies, they must first demonstrate that their reserves are adequately backed up with bonds. Once this is done, insurers are effectively free to invest elsewhere with the surplus.

It is thus important that concerned insurance regulators review existing rules and policies, identifying potential barriers and providing more flexibility for "doing the right thing". Similarly, they should play an active role in ensuring the validity of insurer climate initiatives. One example would be to review the quality of carbon offsets offered to customers or purchased for in-house use. ${ }^{77}$ The quality and completeness of carbon accounting by insurers (and most other industries) is very uneven; regulators might play a role in improving the procedures used.

Requests or requirements to undertake the sorts of innovative strategies outlined in this report could originate from the insurance regulators. For example, regulators could call for separate rating of hybrid vehicles, keep track of loss experience and ultimately utilise the results to propose differential treatment of customers owning these cars.

Regulators also can call for more complete disclosure of climate risks, both in the core business of insurance underwriting as well as in the selection of weather-sensitive investments that could affect their solvency.

Many regulators have held symposia in their states or established working groups to analyse climate risks and develop policy. These include California, Connecticut, Kansas, Maryland, Pennsylvania and Washington. Recognising the material threat of climate change, the U.S. NAIC created an executive-level task force in 2006 to study the issue in detail. In June 2008, it issued a major white paper with the following key findings:

1. Insurers across all business lines face risks from climate change;

2. Insurer investments are a source of considerable concern as insurers might see the losses they underwrite escalate even as their assets decline in value from climate impacts;

3. Insurance regulators play a critical role in understanding this evolving risk. They must ensure that insurers have adequate liquidity, capital reserves and reinsurance to meet the expected increase in catastrophic loss by educating consumers about the changing risks and forwarding risk-reduction activities to maintain a viable insurance market, as well as by engaging with other policy-makers to advance aggressive climate legislation.

\section{Towards best practices}

Climate change and the global political and public response to it, presents a range of threats and opportunities for corporations in terms of their risk management, growth strategies and brand positioning. The issue is shifting from a peripheral corporate social responsibility concern to a topic for strategic

\footnotetext{
${ }^{77}$ Farenthold (2008)
} 
deliberation among executives and investors worldwide. ${ }^{78}$

\author{
Dr. Celine Herweijer \\ Director, RMS Climate Change Practice
}

Discussions of climate change often convey a "gloom-and-doom" outlook for the future. Yet, as the preceding pages testify, there are a host of actionable opportunities for insurers. They have in common the potential for improving their business position while addressing the risks posed by climate change and contributing to public goods. While the tightening of terms and conditions and upward adjustments of prices will be appropriate in some contexts, these measures should be regarded as only one class of the options available to insurers and, preferably, as a last resort.

The activities described in this paper reflect substantial progress, but much more can be done. As shown in Figure 6, there are a number of particularly notable untapped opportunities. These include products and services for crop insurance, commercial-lines automotive products, liability insurance and risk management, carbon offsets beyond the auto and travel segments, greening warranties and moving beyond insuring green systems or carbon offsets to actually managing customers' risk and improving carbon accounting and project performance. Coverage extensions allowing upgrades to greener technologies upon total loss have now been utilised extensively for buildings, but vast opportunities exist for similar offerings across many other lines of property insurance. While certain green-energy technologies have benefited from new insurance products and services, CCS still remains relatively difficult to insure. Life-health insurers continue to be only marginally active in developing customer-facing initiatives. Regarding insurers in-house energy activities, most remain relatively naive (focusing on efficient lighting, etc.), whereas the more energy/carbon-intensive processes, such as those associated with information technology equipment, are often overlooked. Insurers are increasingly involved in climate and energy research, but must do much more in order to reinforce the underwriting argument for developing green products and services. In many domains, insurers have done more to promote "green" activities than to help customers manage the risks of climate change and adapt to its unavoidable impacts.

A large number of examples are identified in this report. It should be noted that these forward-looking activities are largely modest initiatives and are collectively far from what would constitute a best-practice offering within the insurance industry. No single insurer has achieved what we would consider a comprehensive response, but many are moving in that direction. Many promising strategies have not been tried at all.

Generalised guidelines exist to help companies and asset managers manage climate risks $^{79}$ and identify opportunities posed by climate change. Best practices more tailored to insurers could follow the following 10-point approach:

1. Improve the theory and practice of modelling (and other methods of analysing climate-change risks, where CAT models do not suffice) and of climate science.

\footnotetext{
${ }^{78}$ RMS (2008).

${ }^{79}$ Anderson and Gardiner (2008).
} 
Particular effort should be made to conduct stress tests of a range of plausible scenarios, rather than limiting investigations to predictive middle-of-the-road estimates.

2. Make concerted efforts to restore and maintain the insurability of extreme weather events. This might require partnerships with governments, for example, in the cases of improved land-use planning and enforced building codes.

3. Utilise terms and conditions to foster actuarially motivated "climate-friendly" decisions by customers. This could range from rewarding risk-minimising behaviour to excluding climate change liabilities for those who make imprudent decisions either as emitters of greenhouse gases or as managers of risks associated with climate change.

4. Develop new products, services and financing to facilitate maximum customer utilisation of climate-friendly technologies and practices, especially in cases where they yield loss prevention co-benefits. Craft disaster-resilient approaches that are sustainable and sustainability strategies that are disaster-resilient.

5. Rebalance investment portfolios to recognise climate-related risks to investments and capitalise on opportunities for emerging industries that will participate in climate change solutions.

6. Actively participate in emerging markets for carbon-free energy and carbontrading, both as an investor and as a risk manager.

7. Lead by example, by achieving carbon-neutrality. This includes addressing the climate impacts of real estate owned by the insurer, as well as the carbon footprint of business operations and supply chains and by analysing and disclosing exposures to climate change.

8. Take an active role in the education and training of insurance professionals and customers about climate-related risks and opportunities for minimising them.

9. Actively engage in public policy discussions on climate change.

10. Tighten terms and conditions, withdraw from markets or increase insurance prices only when the aforementioned best practices have been exercised to their fullest cost-effective potential.

Corollary best practices for rating agencies will involve assessing insurers' handling of climate risks. Other trade allies - such as brokers, agents and risk managers - can reinforce the aforementioned best practices on behalf of insurance customers.

Grasping these opportunities is fully consistent with the industry's history as founders of fire departments, early promoters of Underwriters Laboratory and key players in physical risk management. Insurers also have long played a role in public policy, whether it is the ongoing debate about terrorism or advocacy for improved roadway safety.

The opportunities described above can enable individual insurers to differentiate their products from the competition, while enhancing their reputations in the eyes of a public increasingly looking for all quarters of industry to come forward with constructive responses to the climate change threat. Indeed, insurance customers are beginning to demand the types of innovative responses documented in this report.

Sustainable-energy technologies will be deemed particularly relevant if they help address other acute strategic issues faced by insurers. A good example is the rapid 
growth in mould and indoor air quality claims and construction defects litigation; ${ }^{80}$ many of these claims trace back to poor design and application of energy-related systems. The growing insurance risks associated with electricity reliability ${ }^{81}$ are another example that can be addressed, in part, through efficiency and distributed renewable-energy supply solutions. There are even synergies between making buildings energy efficient and less vulnerable to chemical and biological attack, for example, improved ventilation controls used to minimise energy use in normal operation and to protect occupants during an emergency. The crisis of corporate governance is also among the broader strategic issues already troubling insurers, which will only be made more difficult by climate change.

Insurers cannot be expected to capture all of these opportunities single-handedly. In many cases, linkages are called for with other entities outside the insurance industry. Improving building codes so that they make maximal use of hazard-resistant technologies and practices while minimising energy use is an example of a strategy that requires the leadership of local government. As a case-in-point, State Farm chose to re-enter the Louisiana coast market after the state agreed to tighten building codes. ${ }^{82}$ Some initiatives will rely on alliances with energy utilities (e.g. offering financial incentive programmes that simultaneously reward hazard resilience and energy efficiency), as was done in a collaborative promotion of fire-safe, energy-efficient light fixtures between FM Global company and Boston Edison. ${ }^{83}$

It is important to anticipate and avoid inadvertent adverse side effects of carbon-reduction strategies. ${ }^{84} \mathrm{~A}$ well-worn example is degraded indoor air quality as a result of the overtightening of buildings. In many cases, these concerns are unfounded, but in others they are legitimate (but surmountable). An example of the latter is that small/light cars exist that are as safe or safer than SUVs. ${ }^{85}$ Concerning energy supply issues, questions have arisen ${ }^{86}$ about unquantified liabilities associated with proposals to capture carbon dioxide at the point of production and inject it, hopefully safely and permanently, into the Earth or seabed. The insurance sector might be unwilling to insure a rebirth of nuclear power, argued by some to be an important climate mitigation strategy.

Given that insurance is the world's largest economic sector and that insurers reach virtually every consumer and business in developed countries, the prospect for their involvement in the development and promotion of climate change mitigation and adaptation strategies stands as an immense but, as yet, largely untapped opportunity.

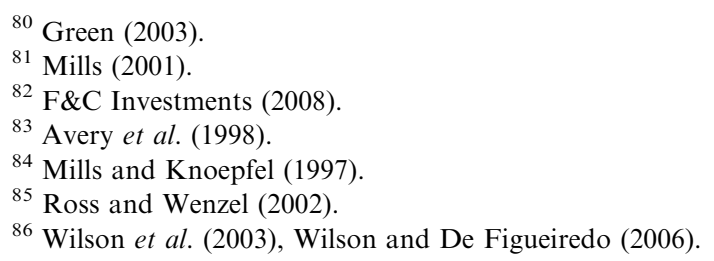




\section{Getting started}

The longest journey begins with a single step.

$$
\text { Attributed to Lao-Tzu (c 604-c } 531 \text { B.C.) }
$$

The preceding best practices discussion establishes achievable yet ambitious goals. Companies wishing to develop innovative responses to climate change must juggle these aspirations with the press of everyday business and the need to develop revenues in the near term. Yet, while strategic thinking can be dismissed as a luxury, it is critical to remaining competitive. Nonetheless, insurance companies can rightfully ask: "Where do we start?" The following checklist summarises initial steps that innovative insurers have taken in order to establish and embed a corporate platform from which longer-range best practices can be pursued:

(i) Approach climate change as an ERM issue.

(ii) Establish a "climate champion" from the company's board.

(iii) Appoint a point-person on climate.

(iv) Develop a written corporate position on climate change.

(v) Prepare an annual environmental report.

(vi) Model better - work to better reflect climate change in CAT modelling.

(vii) Listen to and support customers.

(viii) Set priorities.

(ix) Forge partnerships.

(x) Walk the talk - practice sustainability in-house before admonishing customers to do so. Educate and train insurance professionals and trade allies.

\section{Outlook}

To assume that the current financial turmoil has eclipsed the need for insurers to decisively prepare for climate change is akin to assuming that because one hurricane has hit, there is no need to prepare for a second. ${ }^{87}$

Director of Science and Systems, Climate Risk Pty Ltd

As the implications of climate change come into sharper focus, insurers will devote increased attention and resources to the issue. Availability and affordability will continue to be a problem and various parties will continue to seek climate risk disclosure from insurers - both on the underwriting and asset management issue. High-stakes liability exposures will be an area of particular attention and a wave of exclusions under traditional covers would not come as a surprise. ERM will increasingly be seen as a valuable framework for addressing climate risks.

\footnotetext{
${ }^{87}$ Climate Risk (2008).
} 
A new wave of green projects and services can be expected. Challenges and opportunities include bringing promising products and services to scale, continuing to identify and fill coverage gaps and becoming more sophisticated in identifying and confirming the performance benefits of green improvements. It has not yet been demonstrated how some insurance lines might respond to climate change and a number of market segments have not yet been served with a single "green" insurance product or service. As insurer activities obtain more prominence, they also will be subject to more scrutiny and expectations that they are not simply greenwashing.

New players will continue to enter the market, both from within and outside of the insurance sector. Insurance actuarial organisations made significant efforts in 2008 to engage in the issue and their efforts are likely to expand considerably. Non-insurance entities - governments, non-governmental organisations, energy companies, etc. - will continue to seek innovative partnerships in delivering climate change solutions.

With increasing scale of insurer initiatives, the imperative to close knowledge gaps will become more visible. Insurers will need to engage more in research across a wide domain of topics. This includes the integration of climate modelling and catastrophe modelling, exploring the comparative risk profiles of "low-carbon" technologies to help inform underwriting as well as public policy. Across many lines (including liability) increasing recognition of potential gaps between promised and actual performance of green technologies, carbon offsets, etc., will create pushback against insurers' "greening" claims while spawning new and better products and services.

One of several "elephants in the room" is the failure to link sustainability and disaster-resilience. In fact, one cannot exist without the other. Insurers are perfectly placed to make the case for unifying "green" and "disaster-resilient" practices across many domains (construction, energy, agriculture, land use), yet scant effort has been exerted in this regard. It will become increasingly incumbent on insurers to demonstrate the loss-reducing benefits of the green technologies and services that they reward yield benefits. Loss-prone infrastructure cannot be truly "sustainable". ${ }^{88}$ The creation of technologies and services combining risk- and carbon-management analysis and remediation could prove to be a powerful and costeffective formula for simultaneously reducing greenhouse-gas emissions while bolstering disaster resilience. Land-use planning as well as codes and standards are also yet to adequately embrace this approach and there is much more that insurers can do to help customers adapt to unavoidable climate changes.

The global financial crisis that emerged in late 2008 will certainly have repercussions for insurers and their climate change initiatives. It might be the case that corporatelevel activities not tied directly to revenue generation will be curbed. However, much of the existing activity has become embedded in the operations of insurance companies and if insurer statements about the significant customer demand and reception for new products and services hold true, then prudent companies can be expected to stay the course and perhaps even ramp up their efforts more quickly to keep pace with competition and with consumers looking for new value in insurance services. While there will be pressure in many regions to "get back to basics" and ensure that climate

\footnotetext{
${ }^{88}$ Patton (2008b).
} 
356

initiatives have business materiality, it also will become clear that vulnerability to climate change only increases when non-weather catastrophes such as the current financial turmoil serve to make society less resilient. Meanwhile the new Obama administration in the United States will no doubt advance legislation and urge insurers and the rest of the private sector to double their efforts to green the economy and prevail over the risks posed by global climate change.

While the prolific development of green insurance initiatives proves that the economy and environment can go hand-in-hand, some even within the industry caution against limiting insurer climate change responses strictly to those that are immediately profitable. Just as the slogans of many insurers portray them as guardians of human well-being, acting on climate change is also paramount to the deeper integrity of the industry.

The industry should not be afraid to be bold on this issue. In fact, this might just be the perfect opportunity for the insurance industry to demonstrate how it really does advance the interests of all of us ahead of its own, narrower commercial interests. ${ }^{89}$

\section{Acknowledgements}

This paper is derived from a more extensive annual report entitled "From Risk to Opportunity: Insurer Responses to Climate Change," commissioned by Andrew Logan U.S.-based Ceres (Mills, 2009), a national coalition of investors, environmental groups and other public-interest organisations working with companies to address sustainability challenges such as climate change. Ceres also directs the Investor Network on Climate Risk, a group of 70 institutional investors from the United States, Europe and Canada that collectively manage more than $\$ 7$ trillion in assets. This project was sponsored by grants from Blue Moon Fund, The Kresge Foundation, The Pew Charitable Trusts, Rockefeller Brothers Fund, Rockefeller Family Fund, Energy Foundation and Surdna Foundation. The original compilation of case studies was performed by Lawrence Berkeley National Laboratory with sponsorship from the U.S. Department of Energy and U.S. Environmental Protection Agency. Marta Darby provided excellent copy-editing assistance and Chris Clark of Cave Dog Studio produced the graphics.

\section{References}

ABI (2007) Adapting to Our Changing Climate: A Manifesto For Business, Government and the Public, London, UK: Association of British Insurers.

ABI (2008) Consultation on Proposals for a Scottish Climate Bill: Response by the Association of British Insurers, London, UK: Association of British Insurers, April.

Anderson, M. and Gardiner, D. (2008) Managing the Risks and Opportunities of Climate Change: A Practical Toolkit for Investors, Boston, MA: Ceres and the Investor Network on Climate Risks, April.

Aon (2007) Will insurers be burned by the climate change phenomenon? September.

Arnold and Porter, LLP (2008) Climate Change Litigation Chart, working paper Washington, DC.

Avery, D., Mills, E., Breighner, M. and Naylis, J. (1998) 'Campus lighting - Lighting efficiency options for student residential living units: A study at Northeastern University, Boston, Massachusetts', University Risk Management and Insurance Association's URMIA Journal 1999, 44-52, Chevy Chase, MD.

\footnotetext{
${ }^{89}$ Gambrill (2007).
} 
Bennett, R.A. (2007) 'Could soaring gas prices fuel opposition to credit scoring for auto underwriting?' National Underwriter: Property \& Casualty 14, 6 August 2007.

Bhambhani, D. (2008) 'DOE reaches agreement with company over disputed energy star refrigerators', Inside DOE 8, 1 December 2008.

Carroll, A. and Seakins, K. (2008) 'Insurance for commercial IGCC projects is breaking new ground', $G T W$ IGCC Reference Guide, pp $20-21$.

CAS (2003) Overview of Enterprise Risk Management, Casualty Actuarial Society, Enterprise Risk Management Committee, p. 61, Arlington, Virginia, USA.

CEA: The European Insurance and Reinsurance Federation (2007) Reducing the social and economic impact of climate change and natural catastrophes: Insurance solutions and public-private partnerships, July.

Climate Risk (2008) From risk to advantage: General insurers as key agents for climate change adaptation, Prepared for Zurich Financial Australia.

Climateandinsurance.org (2008) Takefive interview with Howard Mills, National Association of Mutual Insurance Companies from www.climateandinsurance.org/takefive/bio_hMills.html.

Consumer Reports (2009) Chilling Numbers on Fridge Efficiency 42, January.

Del Percio, S. (2008) 'Shaw Development v. Southern Builders: The Anatomy of America's First Green Building Litigation', from www.greenbuildingsnyc.com/2008/08/20/the-anatomy-of-americas-first-greenbuilding-litigation/, accessed 20 August 2008.

Dlugolecki, A. (2006) Adaptation and vulnerability to climate change: The role of the finance sector, United Nations Environment Programme, November.

Environmental Defense (2007) Blown away: How global warming is eroding the availability of insurance coverage in America's coastal states, Washington, D.C., USA.

Electric Power Research Institute (2007) The power to reduce $\mathrm{CO}_{2}$ emissions: The full portfolio, prepared for the EPRI 2007 Summer Seminar, The EPRI Energy Technology Assessment Centre.

Ernst \& Young (2008) Strategic Business Risk 2008: Insurance, EYG no. EG0015.

F\&C Investments (2008) In the front line: The insurance industry's response to climate change, London, UK. Farenthold, D.A. (2008) 'Value of U.S. house's carbon offsets is murky', Washington Post, 28 January, A01.

Friedman, S. (2007) 'Be practical on climate risk, insurers told', National Underwriter: Property \& Casualty 10, 12 November 2007.

Gale, A. (2003) Actuaries in Australia-Current developments, Presentation to the Actuarial Society of Hong Kong, 26 July.

Gambrill, D. (2007) 'Changing the world', Canadian Underwriter, October.

GAO (2007) Climate change: Financial risks to federal and private insurers in coming decades are potentially significant, U.S. Government, Washington D.C.

Green, M. (2003) 'A hole in the wall', Best's Review 51, July.

Green, M. (2008) 'The green wave', Best's Review 32, March.

Greenwald, J. (2008) 'Investments cat losses hit results at Swiss Re', Business Insurance, 10 November, p. 21.

Hays, D. (2008) 'Auto insurers challenge call for rate cuts', National Underwriter: Property \& Casualty 718/ 25 August.

Hunter, R. (2008) 'Gas prices should impact rates for auto insurance', National Underwriter: Property \& Casualty 34, 27 October 2008.

IIABA (2007) Consumers Can Minimize Homeowner Insurance Non-Renewals, Rate Increases. Independent Insurance Agents \& Brokers of America News Release. 7 June, Washington, D.C., USA.

IDNR (2000) Insurance Industry Participation in Promotion of Building Energy Codes, prepared by the Centre for Business and Economic Research, Louisiana State University, for Iowa Department of Natural Resources, August.

Innovest (2007) Carbon Disclosure Project Report 2007, Innovest Strategic Value Advisors.

Insurance Journal (2008) 'Nobel Peace Prize winners honor catastrophe model pioneer Clark', Insurance Journal, , 22 May 2008.

Insurance Times (2008) 'Munich Re and Carbon Re set pp alliance', Insurance Times, 22 April 2008.

Kramer, D. (2008) 'DOE urgent to proceed more deliberately with global plan to expand nuclear power', Physics Today 19, July.

Lavoie, D.R. (2006) 'Katrina puts spotlight back on mold', National Underwriter: Property \& Casualty 16, 10 April 2006. 
Lenckus, D. (2008b) 'Insurers have yet to restrict climate change-related losses', Business Insurance 23, 17 November 2008.

Lifsher, M. (2008) 'California insurance commissioner backs pay-as-you-drive policies', Los Angeles Times, 28 August 2008.

Lloyd's of London (2008) Directors in the Dock: Is Business Facing a Liability Crisis? survey of 183 boardlevel corporate executives conducted by the Economist Intelligence Unit.

MacDonald-Smith, A. (2007) Climate Change to Boost Insured Losses, Allianz Says, Blomberg, 18 September 2007.

Maier, R. (2006) 'Natural disasters create pollution hazards', National Underwriter: Property \& Casualty 16, 24 July 2006.

Marsh (2006) Risk Alert: Climate Change: Business Risks and Solutions 5(2): 36.

Marsh (2007) Sustainability Report: 2007, Marsh \& McLennan Company, New York, NY, USA.

Marsh (2008) The Green Built Environment in the United States: 2008 Year-end Update of The State of the Insurance Marketplace, Report \#MA9-10017. New York, p. 19.

MEAG (2008) 'MEAG Launches the KlimaStrategie Equity Fund', news release, 13 March 2008.

Mills, E. (2001) 'When the lights go out', Best's Review July: 73-77.

Mills, E. (1999) The Insurance and Risk Management Industries: New Players in the Delivery of Energyefficient Products and Services, Prior versions published in Proceedings of the ECEEE 1999 Summer Study, European Council for an Energy-Efficient Economy (31 May - 4 June 1999) Mandelieu, France, updated in Energy Policy 31: 1257-1272.

Mills, E. (2004) Insurance as an Adaptation Strategy for Extreme Weather Events in Developing Countries and Economies in Transition: New Opportunities for Public-Private Partnerships, Lawrence Berkeley National Laboratory Report No. 52220.

Mills, E. (2005) 'Insurance in a climate of change', Science 308(5737): 1040-1044.

Mills, E. (2007) 'The role of NAIC in responding to climate change', UCLA Journal of Environmental Law and Policy 26(1): 129-168, Originally published as Testimony to the National Association of Insurance Commissioners, 8 December 2006, San Antonio, TX.

Mills, E. (2009) 'From risk to opportunity 2008: Insurer responses to climate change', Ceres.

Mills, E. and Knoepfel, I. (1997) Energy Efficiency Options for Insurance Loss Prevention, Proceedings of the ECEEE Summer Study, 9-14 June, Prague.

Mills, E., Roth Jr., R.J. and Lecomte, E. (2006) 'Availability and affordability of insurance under climate change: A growing challenge for the U.S.', Journal of Insurance Regulation 25(2): 109-149.

Munich Re (2008b) 'Will Climate Change Alter Liability Risks? workshop report from www.munichre.com/ en/ts/geo_risks/climate_change_and_insurance/climate_liability_workshop/default.aspx.

NAIC (2008) 'The potential impacts of climate change on insurance regulation', Kansas City, Missouri, USA.

NRDC (2008) 'Acknowledging growing financial risk, top banks issue new emission-based principles for power plant loans', News release.

Orleans, D. (2007) 'Feeling the heat how greenhouse gas emissions standards and trading systems are creating risks and opportunities around the world', Willis Environmental Risk Newsletter, November(11).

Patton, L. (2008a) 'Beyond rising sea levels: Using the insurance asset to manage risk and maximize opportunity in the "green economic" paradigm shift', European Business Review, July/August.

Patton, L. (2008b) 'Beyond rising sea levels: The importance of the insurance asset in the process of accelerating delivery of new technology to market to combat climate change', European Business Review, September/October. July/August.

Postal, A.D. (2008) 'Flood rating system flawed, GAO warns', National Underwriter: Property \& Casualty 8 December 2008.

PricewaterhouseCoopers (2007) "Too Much Regulation" Tops Insurance Risks, Centre for the Study of Financial Information and PricewaterhouseCoopers, news release, 25 May.

Prudential (2008) 'Prudential invests in wind power', from www.prudential.com/view/page/ 14246 ? seg $=2 \&$ name $=$ prudentialinvestsinwindpower.

RMS (2008) 'RMS develops new climate change risk screening service', company news release, 8 August 2008. 
Ross, C., Mills, E. and Hecht, S. (2007) 'Limiting liability in the greenhouse: Insurance risk-management in the context of global climate change', Stanford Environmental Law Journal and the Stanford Journal of International Law, Symposium on Climate Change Risk 26A/43A: 251-334.

Ross, M. and Wenzel, T. (2002) An Analysis of Traffic Deaths by Vehicle Type and Model, LBNL Report No. 49675.

Ruquet, M.E. (2007) 'Oil producers scramble for coverage', National Underwriter Online News Service, 20 April 2007.

Sandridge, H. (2008) 'Building business', Best's Review, March.

Shapiro, S. (2008) 'Airlines hitting financial turbulence amid soaring prices for aviation fuel', Business Insurance, 15(September): 16.

State Farm (2007) 'Climate change', from www.statefarm.com/about/media/current/climate.asp.

Swiss Re (2008) 'Sigma', World Insurance: 2007.

Swiss Re (2009) 'Sigma', Natural Catastrophes and Man-made Disasters in 2008, February 2009.

Stern, N. (2007) The Economics of Climate Change: The Stern Review, Cambridge University Press, Cambridge/New York.

Taylor, R. (2008) Hedging Bets on the Green Gamble: Addressing Risks in the Design, Construction and Operation of Green Buildings, AON Environmental Services Group, p. 25, Chicago, USA.

Trabucchi, C. and Patton, L. (2008) 'Storing carbon: Options for liability risk management, financial responsibility', World Climate Change Report, 2008(170): 03/09/2008, The Bureau of National Affairs.

UNEP (2007) Insuring for Sustainability, United Nations Environment Programme, Nairobi, Kenya.

Whitfield, N. (2008) 'Vanpools cut costs, increase some risks', Business Insurance, 1 September 2008: 1.

Wilson, E.J. and de Figueiredo, M.A. (2006) 'Geologic carbon dioxide sequestration: An analysis of subsurface property law', Environmental Law Review 36: 10114.

Wilson, E.J., Friedmann, S.J. and Pollak, M.F. (2007) 'Research for deployment: Incorporating risk, regulation and liability for carbon capture and sequestration', Environmental, Science and Technology 41: 5945-5952.

Wilson, E.J., Johnson, T.L. and Keith, D.W. (2003) 'Regulating the ultimate sink: Managing the risks of geologic $\mathrm{CO}_{2}$ storage', Environmental Science and Technology 37: 3476-3483.

Zurich (2008) Zurich Launches Market-focused Climate Initiative, company news release, 21 January 2008.

\section{About the Author}

Dr. Evan Mills is a staff scientist at the U.S. Department of Energy's Lawrence Berkeley National Laboratory, one of the world's leading research centres on energy and environment and Research Affiliate with the Energy \& Resources Group at University of California, Berkeley. He works in the areas of energy management and the impacts of climate change on economic systems, particularly with respect to the insurance sector. He has published more than 200 technical papers and reports and has contributed to 10 books, including the U.S. Climate Change Science Program's most recent assessment of climate change impacts. He served as co-leader of the Intergovernmental Panel on Climate Change (IPCC) Third Assessment Report's chapter on insurance. http://insurance.lbl.gov. 